\title{
Determinant Factors of Development Entrepreneurial Education: Lesson from Senior High School in Indonesia
}

\author{
Ari Saptono ${ }^{1}$, Agus Wibowo ${ }^{1, *}$, Bagus Shandy Narmaditya ${ }^{2}$, Djoko Dwi Kusumojanto², \\ Meidyana Hermawati ${ }^{1}$
}

\author{
${ }^{1}$ Faculty of Economics, State University of Jakarta (Universitas Negeri Jakarta), Indonesia \\ ${ }^{2}$ Faculty of Economics, State University of Malang (Universitas Negeri Malang), Indonesia
}

Received October 13, 2019 ; Revised November 20, 2019; Accepted November 26, 2019

Copyright $(2019$ by authors, all rights reserved. Authors agree that this article remains permanently open access under the terms of the Creative Commons Attribution License 4.0 International License

\begin{abstract}
This study aims to obtain information and knowledge related to entrepreneurial education, subjective norm, and entrepreneurial attitude towards entrepreneurial intention senior high school student. This research followed a survey method with proportional random sampling technique while the data was primary data obtained by 251 respondents from three senior high school in Jakarta, Indonesia. Furthermore, the data were analyzed using AMOS Structural Equation Modeling (SEM) in order to understand the direct influence and indirect effect. This research was conducted for about six months from September to February 2019. The findings of this study indicate that entrepreneurial education does not effect on entrepreneurial intention. Meanwhile, the entrepreneurial education has a relationship with entrepreneurial attitude. In respect, the subjective norm has a correlation with entrepreneurial intention, subjective norm has an effect on entrepreneurial attitude, and entrepreneurial attitude has an impact entrepreneurial intention. From these findings, it can be seen that the entrepreneurial attitude is a mediating variable between entrepreneurial education and entrepreneurial intention as well as between subjective norm and entrepreneurial intention variable.
\end{abstract}

Keywords Entrepreneurial Education, Subjective Norm, Entrepreneurial Attitude, Entrepreneurial Intention

\section{Introduction}

Entrepreneurs play an essential role in enhancing job opportunities and economic growth. Kritikos (2014) mentioned that entrepreneurs boost economic growth by establishing new technologies, products, and services. Besides, innovations in producing goods and services will lead to a higher number of businesses that will improve the job opportunity. With the increasing number population in Indonesia, unfortunately, it is not linear with the increasing number of an entrepreneur. In more detail, the entrepreneurial and population ratio in 2018 was about 3.1 percent (Puspayoga, 2018). Therefore, it needs to foster entrepreneurial spirit by motivating individuals started earlier both in the school and in the family (Bettinelli et al., 2014). Also, an effort to increase the number of entrepreneurship is to increase the intention of entrepreneurship for students.

Several factors are affecting an individual to be an entrepreneur, such as entrepreneurial education, subjective norm, entrepreneurial attitude, etc. Entrepreneurial education generally reflects the transmission of mindset and expertise specifically related to entrepreneurial outcomes (Valerio et al., 2014). Also, Maisaroh et al. (2013) mentioned that entrepreneurial education aims at increasing knowledge and influencing attitudes to entrepreneurial intentions. Utami (2017) added that entrepreneurial education engages the student's knowledge about entrepreneurs and provides an understanding of the challenges and opportunities in conducting business. According to Hussain (2015), entrepreneurial education does not only enhance the knowledge and information skills needed to pursue opportunities but equips individuals with analytical skills and knowledge about entrepreneurial processes that enhance entrepreneurial assessment. Several previous studies suggested that entrepreneurial education has a relationship with entrepreneurial intention such as Utami (2017); Wibowo \& Pramudana (2016); and Hejazinia (2015).

In the other hand, the relationship between subjective norm and entrepreneurial intention has shown by several prior studies such as Krithika \& Venkatachalam (2014); Listyawati (2017); Mirawati et al. (2016); Mohammed (2017); Astuti \& Martdianty (2012). Mohammed (2017) remarked that subjective norm is the assumptions of a 
person who participate in and hope for that person in doing something and to what extent these desires are fulfilled. Astuti \& Martdianty (2012) stated the subjective norm is a form of environmental influence that affects individuals having the intention to do something. In addition, Widyastuti \& Sumiati (2013); Susetyo \& Lestari (2014) confirmed that subjective norms had a positive influence on the intention to do business. Other studies by Yaghmaei \& Ghasemi (2015); Alimehmeti \& Shaqiri (2015) proved a positive relationship between behavioral attitudes and entrepreneurial intention. Then, it can be concluded that there is a mutually influential relationship between entrepreneurial education, subjective norm, and entrepreneurial attitude towards entrepreneurial intention.

However, in fact, several researchers remarked the different findings (Cahyono, 2014; Bae et al., 2014; Gerba, 2012; Lorz et al., 2011). First, Cahyono (2014) said that entrepreneurial education has no effect on entrepreneurial intention. In addition, research was conducted by Bae et al. (2014) showed that there is no effect of entrepreneurial education on entrepreneurial intention. Indeed, Lorz et al. (2011) revealed that there was no significant entrepreneurial education toward entrepreneurial intention. In the other studies such as Gerba (2012) resulted the influence of entrepreneurial education on entrepreneurial intention in business and engineering students in Ethiopia. Furthermore, Kusmintari et al. (2017); Hejazinia (2015); Utami (2017) stated that entrepreneurial education has a relationship with entrepreneurial intention. Therefore, this study insights from the debatable findings on the relationship between entrepreneurial education, subjective norm, and entrepreneurial attitude toward entrepreneurial Intention. Secondly, this research provides different subject matter related to the topic from senior high school to assist in which previous studies was conducted in the university and vocational high school.

\section{Methodology}

This is a quantitative research using Structural Equation Model (SEM). The data were collected from questionnaires which filled by senior high school students. The population was the students from senior high school in Jakarta in Indonesia while the samples were determined purposively to 67 students of grade IX in Senior High School, 78 students of grade X and 106 students of grade XI, respectively. In total, 251 students were participated in the study and it was conducted approximately one year. The entrepreneurial education program is mandatory from ministry of education for senior high school in Indonesia to enhance students' value, ability, and attitude facing opportunities and challenges to be an entrepreneur which was started in the beginning of first year. The program is not only about providing entreprenurship theories but also giving the real experiences.

To measure entrepreneurial education, this study using four indicators from Denanyoh et al. (2015), subjective norm using two indicators from Kolvereid (2006) and Krueger (2000), entrepreneurial attitude of three indicators from Linan \& Chen (2009), and entrepreneurial intention of three indicators were adapted from Kusmintarti et al. (2017); Susetyo et al. (2014). In addition, researchers used a Likert scale in obtaining the data from the point 1 for statements strongly disagree to point 5 for statements strongly agree.

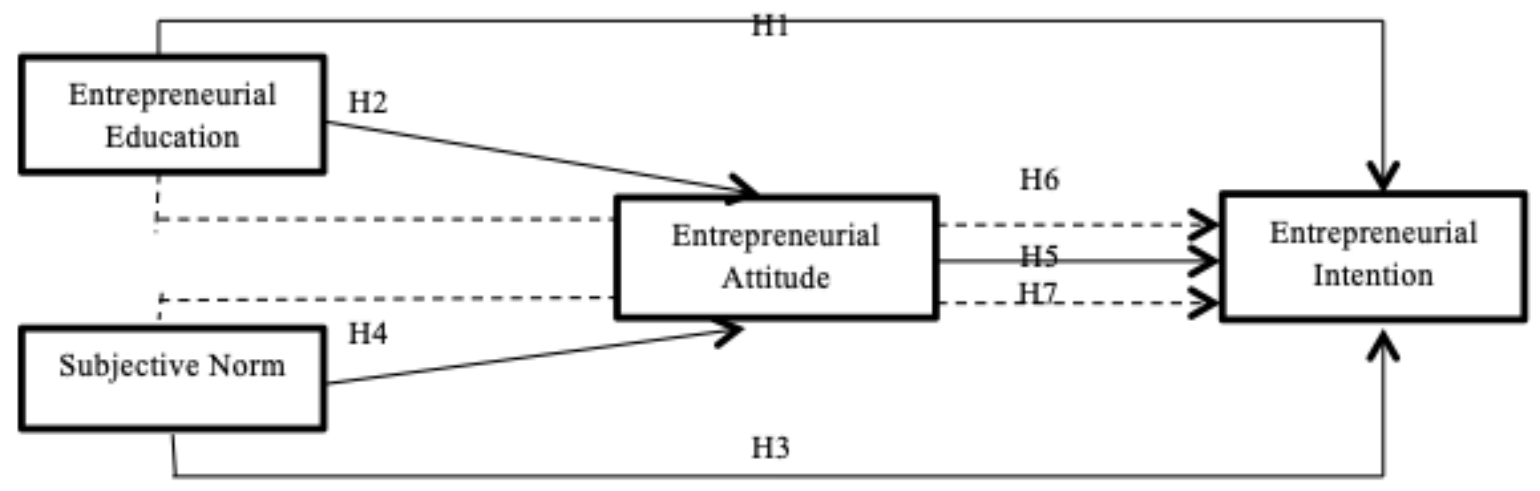

Figure 1. The Theoretical Framework 


\section{Results and Discussion}

This study conducted two stages in analyzing data. In the first stage, researchers followed an exploratory factor analysis test using SPSS version 18. This analysis is a way to validate data as well as to explore dimensions and maintain firm indicators (Allen \& Bennett, 2010), and followed by a reliability test. According Jakobson et al. (2005), the Cronbach Alpha value can be said to be reliable if the magnitude is more than 70 percent or 0.70 . Second, it was conducted a confirmatory factor analysis using AMOS version 24. Hulland et al. (1996) mentioned that the model tested must have several criteria and cut-off values, namely $\mathrm{p}$ (probability) $\geq 0.5$ to reach the appropriate model.
CMIN/DF values $\leq 2$ (Tabachnick \& Fidell, 2007), CFI $\geq$ 0.95 (Arbuckle, 1997), and RMSEA of $\leq 0.08$ (Baunmgather \& Homburg, 1996).

\subsection{Exploration Factor Analysis}

Based on the results of exploratory factor analysis which provided in the Table 1 , in total there are 30 factors including entrepreneurial education (8), subjective norm (7), entrepreneurial attitude (7), and entrepreneurial intention (8). All factors had Cronbach's alpha ranging from 0.9287 to 0.9298 , and all were considered to meet the criteria for inclusion in further analysis (See Table 1).

Table 1. The result of Exploratory Factor Analysis

\begin{tabular}{|c|c|c|}
\hline & Dimension and Indicators & Factor Loadings \\
\hline 1 & Entrepreneurial Education & 0.9297 \\
\hline EE8 & Entrepreneurial Education allows me to identify current business opportunities & 0.617 \\
\hline EE7 & Entrepreneurial Education does not make me have the expertise to do business & 0.576 \\
\hline EE6 & Entrepreneurial Education added to my insight in the field of entrepreneurship & 0.573 \\
\hline EE5 & Entrepreneurial Education does not make me understand how to make a business & 0.532 \\
\hline EE4 & I am interested in entrepreneurship after being given entrepreneurial education & 0.640 \\
\hline EE3 & I do not want to start a business even though I got an entrepreneurial education & 0.525 \\
\hline EE2 & Through entrepreneurial education, I came to know how to start a good and right business & 0.554 \\
\hline EE1 & $\begin{array}{l}\text { The steps and SWOT analysis that have been taught in entrepreneurial education made me discourage } \\
\text { entrepreneurship }\end{array}$ & 0.525 \\
\hline 2 & Subjective Norm & 0.9298 \\
\hline SN22 & I do not want to be an entrepreneur even my parents have a business & 0.543 \\
\hline SN21 & My family agreed with my decision to start a business & 0.678 \\
\hline SN20 & My parents provide support to do not be afraid to fail in entrepreneurship & 0.550 \\
\hline SN19 & My family said that being an entrepreneur would add to income & 0.535 \\
\hline SN18 & The speaker at seminar of entrepreneurship made me optimistic being an entrepreneur & 0.628 \\
\hline SN17 & My friends do not support me to start a business & 0.527 \\
\hline SN16 & My teacher support me to start a business & 0.441 \\
\hline 3 & Entrepreneurial Attitude & 0.9287 \\
\hline EA15 & I would rather get a higher salary as an employee than own my business & 0.527 \\
\hline EA14 & I will still choose to be an entrepreneur although so many obstacles & 0.713 \\
\hline EA13 & I prefer to be a leader than choosing a safe job & 0.509 \\
\hline EA12 & Career to be an entrepreneur is not right & 0.706 \\
\hline EA11 & Being an entrepreneur gives me satisfaction & 0.749 \\
\hline EA10 & I would rather be a quality manager than make a new company & 0.578 \\
\hline EA9 & I am not afraid to suffer losses when doing a business & 0.640 \\
\hline 4 & Entrepreneurial Intention & 0.9296 \\
\hline EI23 & I very determined to be an entrepreneur & 0.708 \\
\hline EI24 & I studied entrepreneurship even though I was not sure I did become an entrepreneur & 0.724 \\
\hline EI25 & If I become an entrepreneur, my business will succeed & 0.460 \\
\hline EI26 & I have not made a few steps to start a business & 0.564 \\
\hline EI27 & I started a business after completing education in senior high school & 0.478 \\
\hline EI28 & I will make a business in the future & 0.682 \\
\hline EI29 & I would rather to be an entrepreneur than an employee in the company & 0.675 \\
\hline EI30 & I have not run my own although on a small scale (selling food, online shop, etc.) & 0.440 \\
\hline
\end{tabular}




\subsection{Hypothesis Testing}

Based on SEM calculation, the result of probability score is $0.414, \mathrm{CMIN} / \mathrm{DF}$ score is 1.022, RMSEA score is 0.009 , and CFI score is 0.998 . Presented in the table below, it shows $\mathrm{H} 2, \mathrm{H} 3, \mathrm{H} 4$, and $\mathrm{H} 5$ with $\mathrm{CR}$ scores of 4,111, $2,751,5,652$ and 3,607 , respectively. This score indicates significance. $\mathrm{H} 6$ is significant with $\mathrm{b}=0.006$ and $\mathrm{H} 7$ is significant with $\mathrm{b}=0.002$. In contrast, $\mathrm{H} 1$ was not significant with a CR score of 1.875 (Table 2 and Figure 2).

The results of this study answer seven hypotheses. The first hypothesis (H1) is that there is a direct positive effect on entrepreneurial education on entrepreneurial intention. The results showed that $\mathrm{H} 1$ was not significant with a $\mathrm{CR}$ score of 1.875 . It means that entrepreneurial education does not directly impact on entrepreneurial intention. Schools must be able to evaluate whether the entrepreneurial education programs provided to students are in accordance with the knowledge, skills and attitude competencies needed to create economic value activities from the products produced. The results of the study are in line with the previous study by Cahyono (2014) which mentioned that there is no relationship between enterpreneurial education and enterpreneurial intention. Similarly, other findings were stated by Lorz et al. (2011); Bae et al. (2014) revealed indifference result.

Table 2. Result Summary of Hypotheses Testing

\begin{tabular}{|l|c|c|c|c|c|c|}
\hline & & & & C.R & P & Result \\
\hline H1 & Entrepreneurial Education & $\rightarrow$ & Entrepreneurial Intention & 1.875 & .061 & Insignificant \\
\hline H2 & Entrepreneurial Education & $\rightarrow$ & Entrepreneurial Attitude & 4.111 & $* * *$ & Significant \\
\hline H3 & Subjective Norm & $\rightarrow$ & Entrepreneurial Intention & 2.751 & .006 & Significant \\
\hline H4 & Subjective Norm & $\rightarrow$ & Entrepreneurial Attitude & 5.652 & $* * *$ & Significant \\
\hline H5 & Entrepreneurial Attitude & $\rightarrow$ & Entrepreneurial Intention & 3.607 & $* * *$ & Significant \\
\hline H6 & \multicolumn{2}{|c|}{ Indirect Effect Entrepreneurial Education $\rightarrow$ Entrepreneurial Intention $=0.00670171$} & & Significant \\
\hline H7 & \multicolumn{7}{|c|}{ Indirect Effect Subjective Norm $\rightarrow$ Entrepreneurial Intention $=0.00236122$} & & Significant \\
\hline
\end{tabular}

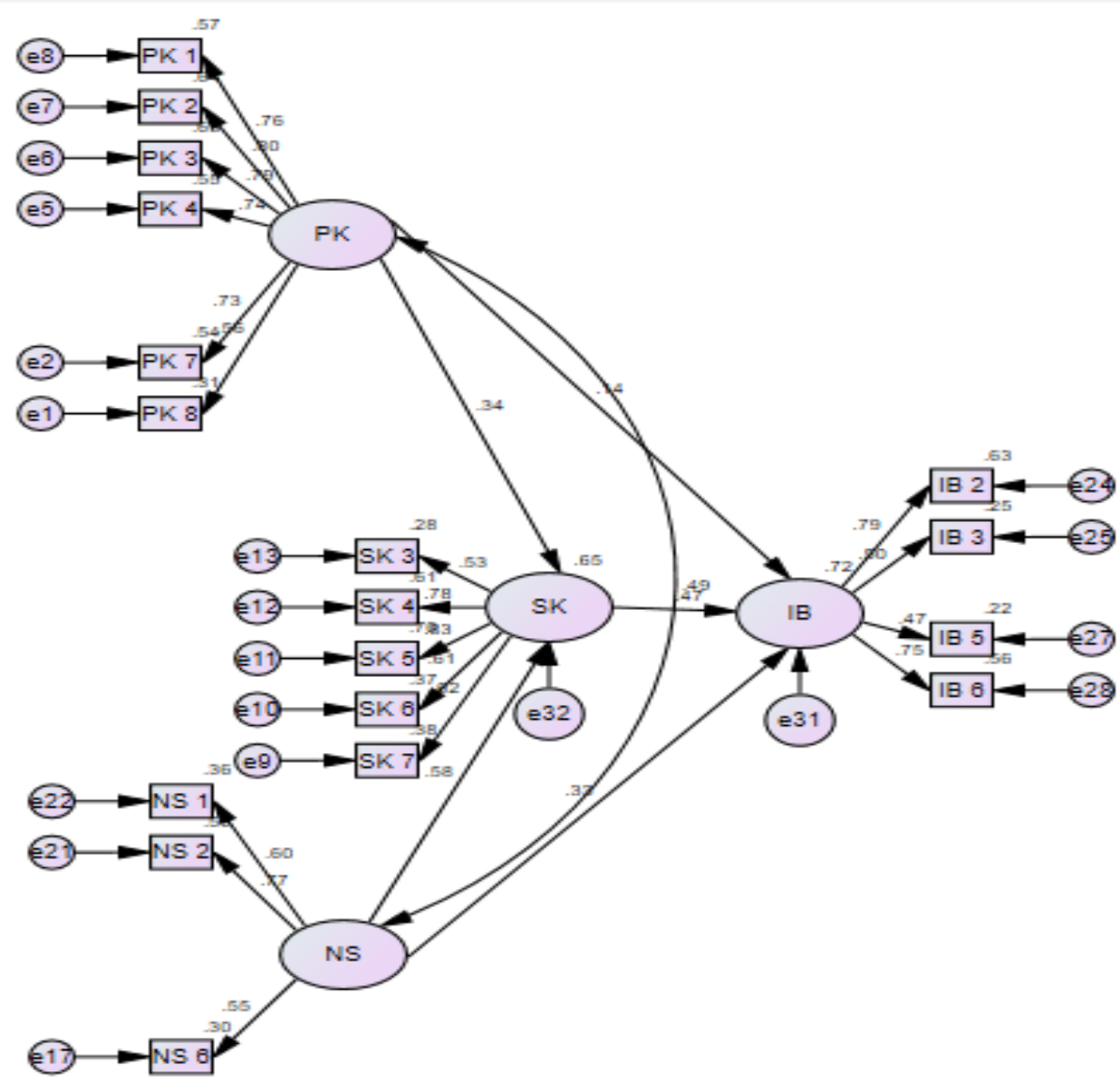

Figure 2. The Result of Structural Equation Model 
In the other hand, the influence of entrepreneurial education on entrepreneurial attitude showed with CR score of 4.111. It implies that entrepreneurial education can explain entrepreneurial attitude. This finding supports previous study by Wahyudiono (2016) which mentioned that entrepreneurship education in accordance with competencies will increase the enthusiasm and attractiveness of students for entrepreneurial attitude. Therefore, schools need to improve entrepreneurial education competencies properly that make students become interested and enthusiastic about entrepreneurial attitude.

The relationship between subjective norm and entrepreneurial intention is showed with CR score of 2.751. This means that subjective norm can explain entrepreneurial intention. The result is in line with the findings of Krithika (2014); Astuti et al. (2012) which mentioned that subjective norm affects entrepreneurial intention. The positive influence given by schools to students can foster strong beliefs within students to be entrepreneurs. In addition, it can provide entrepreneurial seminars that bring in successful business people so that students become confident and intend to really do entrepreneurship. The fourth hypothesis, there is a positive effect between subjective norm and entrepreneurial attitude with a CR score of 5.652. It means that subjective norms can explain entrepreneurial attitude. The results of the study supports previous study by Heuer et al. (2013) which mentioned that there is a correlation between subjective norm and entrepreneur attitude. Schools need to instill good judgment about entrepreneurship. How to make students always excited and interested every time they take entrepreneurial education lessons.

The fifth hypothesis showed that there is a positive direct effect of entrepreneurial attitude on entrepreneurial intention with a CR score of 3.607. It confirmed that entrepreneurial attitude can explain entrepreneurial intention. Thus, the fifth hypothesis is accepted. Indeed, this finding agree with prior study by Yaghmaei et al. (2015); Othman et al. (2012). In this matter, entrepreneurial attitude that has been embedded in students will increase strong confidence in students to entrepreneurship. Furthermore, School need to pay attention to components of student entrepreneurial attitude in order to increase student entrepreneurial intention.

The next hypothesis is that entrepreneurial attitude mediates entrepreneurial education towards entrepreneurial intention. The results found that the value of $b=0.006$ which means entrepreneurial attitude mediate the impact of entrepreneurial education on entrepreneurial intention. The results of this study supports previous study by Wibowo et al. (2016); Cahyono (2014). It remarked that a good entrepreneurial attitude will increase student entrepreneurial intention. With the increase in facilities and infrastructure of entrepreneurial education received by students, it will enhance entrepreneurial attitude and have an effect on increasing student entrepreneurial intention. The seventh hypothesis is that entrepreneurial attitude mediates subjective norm toward entrepreneurial intention. The results found that the value of $b=0.002$ which means entrepreneurial attitude mediate the impact of subjective norm on entrepreneurial intention. Thus the seventh hypothesis is accepted. The results of this study support the findings of Heuer et al. (2013). It revealed that a positive influence (subjective norm) will increase students entrepreneurial attitude so that it will affect students confidence in being truly entrepreneurs.

\section{Conclusions}

This study aims to investigate the impact of entrepreneurial education, subjective norm, and entrepreneurial attitude on entrepreneurial intention in senior high school students in Jakarta, Indonesia. First it can be known that, entrepreneurial education does not have a direct impact on entrepreneurial intention. Meanwhile, entrepreneurial education has a direct positive effect on entrepreneurial attitude. Third, subjective norm has a direct positive impact on entrepreneurial intention. Fourth, subjective norm has a direct positive effect on entrepreneurial attitude. Fifth, entrepreneurial attitude has a direct positive effect on entrepreneurial intention. Sixth, entrepreneurial attitude mediate entrepreneurial education on entrepreneurial intention. Lastly, entrepreneurial attitude mediate subjective norm on entrepreneurial intention. Based on the findings, some suggestions needed, first, schools should pay more attention to supporting entrepreneurial education facilities and infrastructure to develop student creativity such as the existence of an entrepreneurial laboratory, the existence of cooperatives that involve students in their management, and the holding of a bazaar several times a year so that students can be more enthusiastic and earnest in entrepreneurship. Second, schools should not only provide material on entrepreneurship, but also provide support to foster student intentions and also change students' perceptions to be happy and interested in becoming entrepreneurs such as holding seminars on entrepreneurship with successful business people. Third, researchers can set suggestions for academics who will conduct further research with the same concept, if possible can raise some variables that have not been examined in this study so that they can find new and complex findings, especially about entrepreneurial intentions. For further research, it is suggested to provide wider subject of the research by enhancing more schools throughout Indonesia and engaging control group.

\section{Acknowledgements}

We are grateful to anonymous referees and editor of the 
journal for their valuable comments and suggestions an attempt to improve the quality of the article.

\section{REFERENCES}

[1] Alimehmeti, G, \& Shaqiri, G. (2015). Factors Determining Entrepreneurial Intentions: A Case Study from Albania. Academic Journal of Interdisciplinary Studies, 4(3), 233-240.

[2] Allen, P.J., \& Bennett, K. (2010). PASW statistics by SPSS: A practical guide. Version 18.0. Cengage Learning.

[3] Astuti, R. D, \& Martdianty, F. (2012). Students' Entrepreneurial Intentions by Using Theory of Planned Behavior The Case in Indonesia. The South East Asian Journal Management, 6(2), 100-143.

[4] Bae, T. J., Qian, S., Miao, C., \& Fiet, J. O. (2014). The Relationship Between Entrepreneurship Education and Entrepreneurial Intentions: A Meta-Analytic Review. Entrepreneurship Theory and Practice, 217-254.

[5] Bettinelli, Cristina \& Alain, Fayolle \& Randerson, Kathleen. (2014). Family Entrepreneurship: A Developing Field. Foundations and Trends ${ }^{\circledR}$ in Entrepreneurship. 10. 161-236. 10.1561/0300000049.

[6] Baumgartner, J., \& Homburg, C. (1996). Applications of structural equation modeling in marketing and consumer research: A review. International Journal of Research in Marketing, 13(2), 139-161. https://doi.org/10.1016/0167-8 116(95)00038-0.

[7] Cahyono, A. E., (2014). Pengaruh Pendidikan Kewirausahaan Melalui Variabel Intervening Teori Perilaku Terencana Terhadap Intensi Berwirausaha Mahasiswa Fakultas Keguruan dan Ilmu Pendidikan Universitas Jember. Jurnal Ekonomi Pendidikan dan Kewirausahaan, 2(2), 252-263.

[8] Denanyoh, R., Adjei, K., \& Nyemekye, G. E. (2015). Factors That Impact on Entrepreneurial Intention of Tertiary Students in Ghana. International Journal of Business and Social Research, 5(3), 19-29.

[9] Hejazinia, R. (2015). The Impact of IT-based Entrepreneurship Education on Entrepreneurial Intention. International Journal of Management, Accounting and Economics, 2(3), 243-253.

[10] Hulland. (1996). Use of Casual Models in Marketing Research: A Review. International Journal of Research in Marketing. Vol. 13, 181-197.

[11] Hussain, A, \& Hashim, N. (2015). Impact of Entrepreneurial Education on Entrepreneurial Intentions of Pakistani Students. Journal of Entrepreneurship and Business Innovation, 2(1), 43-53.

[12] Hussain, A, \& Hashim, N. (2015). Impact of Entrepreneurial Education on Entrepreneurial Intentions of Pakistani Students. Journal of Entrepreneurship and Business Innovation, 2(1), 43-53.

[13] Krithika, J., \& Venkatachalam, B. (2014). A Study on
Impact of Subjective Norms On Entrepreneurial Intention Among The Business Students In Bangalore. IOSR Journal of Business and Management Ver. III, 16(5), 48-50.

[14] Kolvereid, L., \& Isaksen, E. (2006). New business start-up and subsequent entry into self-employment. Journal of Business Venturing, 21(6), 866-885.

[15] Krueger, N.F., Reilly, M.D. and Carsrud, A.L. (2000). Competing models of entrepreneurial intentions. Journal of Business Venturing, Vol. 15 Nos 5/6, pp. 411-432.

[16] Kusmintarti, A, Riwajanti, N. I, \& Asdani, A. (2017). Sikap Kewirausahaan Memediasi Pengaruh Pendidikan Kewirausahaan Terhadap Intensi Kewirausahaan. Jurnal Riset dan Aplikasi: Akuntansi dan Manajemen, 2(4), 45-54.

[17] Linan, F. and Chen, Y. (2009). Development and cross-cultural application of a specific instrument to measure entrepreneurial intentions. Entrepreneurship Theory and Practice, Vol. 33 No. 3, p. 593.

[18] Lorz, M., Volery, T., \& Muller, C. (2011). The Impact of Entrepreneurship Education on Entrepreneurial Intention. University of St. Gallen, School of Management.

[19] Maisaroh, Widyastuti,U., \& Sumiati.A. (2013). Entrepreneurship Education and Its Effect on Entrepreneurial intention: Case Studies in the Faculty of Economics, State University of Jakarta. Proceedings of 23rd International Business Research Conference 18 - 20 November, 2013, Marriott Hotel, Melbourne, Australia, ISBN: 978-1-922069-36-8.

[20] Miralles, Francesc \& Giones, Ferran \& Riverola, Carla. (2016). Evaluating the impact of prior experience in entrepreneurial intention. International Entrepreneurship and Management Journal. 12. 791-813. 10.1007/s11365-0 15-0365-4.

[21] Mirawati, N. M., Wardana, I. M., \& Sukaatmadja, I. P. G. (2016). Pengaruh Sikap, Norma Subjektif, dan Persepsi Kontrol Keperilakuan, Terhadap Niat Siswa SMK di Kota Denpasar. E-Jurnal Ekonomi Dan Bisnis Universitas Udayana, 5(7), 1981-2010.

[22] Mohammed, B.S., Fethi, A., \& Djaoued, O. B. (2014). The Influence of Attitude, Subjective Norms and Perceived Behavior Control on Entrepreneurial Intentions: Case of Algerian Students, 7(6), 274-282.

[23] Susetyo, D, \& Lestari, P. S. (2014). Developing Entrepreneurial Intention Model of University Students (An Empirical Study on University Students in Semarang, Indonesia). International Journal Of Engineering and Management Sciences, 5(3), 184-196.

[24] Tabachnick, B. G., \& Fidell, L. S. (2007). Using multivariate statistics (5th ed.). Boston, MA: Allyn \& Bacon/Pearson Education

[25] Tessema Gerba, D. (2012). Impact of entrepreneurship education on entrepreneurial intentions of business and engineering students in Ethiopia. African Journal of Economic and Management Studies. Vol. 3 No. 2, pp. 258-277. https://doi.org/10.1108/20400701211265036

[26] Utami, C. W. (2017). Attitude, Subjective Norms, Perceived behavior, Entrepreneurship education and Self-efficacy toward entrepreneurial intention University student in 
Indonesia. European Research Studies Journal, 20(2), 475-

495.

[27] Valerio, A., Parton, B., \& Robb, A. (2014). Entrepreneurship Education and Training Programs around the World Dimensions for Success. Washington, D. C: The World Bank.

[28] Wibowo, S., \& Pramudana, K. A. S. (2016). Pengaruh Pendidikan Kewirausahaan Terhadap Intensi Berwirausaha yang Dimediasi oleh Sikap Berwirausaha. E-Jurnal Manajemen Unud, 5(12), 8167-8198.

[29] Yaghmaei, O, \& Ghasemi, I. (2015). Effects of Influential Factors on Entrepreneurial Intention of Postgraduate Students in Malaysia. International Letters of Social and Humanistic Sciences Online: 2015-05-07, Vol. 51, 115-124. 